\title{
Sympatric occurrence of Ixodes ricinus with Dermacentor reticulatus and Haemaphysalis concinna and the associated tick-borne pathogens near the German Baltic coast
}

\author{
Cristian Răileanu' ${ }^{1}$ Oliver Tauchmann ${ }^{1}$ and Cornelia Silaghi ${ }^{1,2^{*}}$
}

\begin{abstract}
Background: Ixodid ticks from the Northern Hemisphere have registered a northward expansion in recent years, and Dermacentor reticulatus is such an example in Europe, its expansion being considered a result of climate change alongside other factors. The aim of this study was to identify the composition of questing tick species and the associated pathogens at different sites near the German Baltic coast.

Methods: Questing ticks were collected monthly at four sites (May-November, 2020), mainly grasslands, and in October and November 2020 at a fifth site. Molecular screening of ticks for pathogens included RT-qPCR for the tickborne encephalitis virus (TBEV), qPCR for Anaplasma phagocytophilum, PCR for Babesia species and Rickettsia species, and nested PCR for Borrelia species.

Results: Altogether 1174 questing ticks were collected: 760 Ixodes ricinus, 326 D. reticulatus and 88 Haemaphysalis concinna. The highest activity peak of I. ricinus and D. reticulatus was in May, in June for $\mathrm{H}$. concinna while a second peak was observed only for I. ricinus and D. reticulatus in September and October, respectively. All samples tested negative for TBEV. For A. phagocytophilum, 1.5\% of I. ricinus adults tested positive while the minimum infection rate (MIR) in nymphs was $1.3 \%$. This pathogen was found in $0.6 \%$ of D. reticulatus. Babesia spp. were detected in I. ricinus (18.2\% adults, $2.1 \%$ MIR in nymphs) and H. concinna (13.3\% adults, 9.7\% MIR in nymphs). Borrelia spp. were present only in I. ricinus (49.1\% adults, 11.9\% MIR in nymphs), while Rickettsia spp. were detected in I. ricinus (14\% adults, 8.9\% MIR in nymphs) and D. reticulatus (82\%). Co-detection of pathogens was observed in $26.6 \%$ and $54.8 \%$ of positive I. ricinus adults and nymph pools, respectively, while one D. reticulatus tested positive for A. phagocytophilum and Rickettsia spp. The most common co-infection in I. ricinus adults was Babesia microti and Borrelia afzelii (12.3\% of positive ticks).

Conclusions: The results of this study confirm the northern expansion of D. reticulatus and H. concinna in Germany. The detailed data of the infection levels at each location could be useful in assessing the risk of pathogen acquisition following a tick bite.
\end{abstract}

Keywords: Ixodid ticks, Tick-borne pathogens, Co-infections, German Baltic coast

*Correspondence: cornelia.silaghi@fli.de

${ }^{1}$ Institute of Infectology, Friedrich-Loeffler-Institut, Suedufer 10,

17493 Greifswald-Insel Riems, Germany

Full list of author information is available at the end of the article

(c) The Author(s) 2022. Open Access This article is licensed under a Creative Commons Attribution 4.0 International License, which permits use, sharing, adaptation, distribution and reproduction in any medium or format, as long as you give appropriate credit to the original author(s) and the source, provide a link to the Creative Commons licence, and indicate if changes were made. The images or other third party material in this article are included in the article's Creative Commons licence, unless indicated otherwise in a credit line to the material. If material is not included in the article's Creative Commons licence and your intended use is not permitted by statutory regulation or exceeds the permitted use, you will need to obtain permission directly from the copyright holder. To view a copy of this licence, visit http://creativecommons.org/licenses/by/4.0/. The Creative Commons Public Domain Dedication waiver (http://creativeco mmons.org/publicdomain/zero/1.0/) applies to the data made available in this article, unless otherwise stated in a credit line to the data. 


\section{Background}

The ixodid tick fauna in Germany is represented by a total of 19 species [1]. In addition to these, two tick species of the exotic Hyalomma genus (Hyalomma marginatum and Hyalomma rufipes) have been recently reported in Germany alongside their ability to develop from nymphs to adults under the local climatic conditions [2]. Another imported species in Germany, Rhipicephalus sanguineus sensu lato (s.l.) was found on dogs after travellers returned from regions with a tropical or subtropical climate. Additionally, it is considered that this tick species can survive indoors during the winter [1].

The geographic range of Ixodes ricinus extends on longitude from $10^{\circ} \mathrm{W}$ (Ireland) to $45^{\circ} \mathrm{E}$ (Ural Mountains, Russia) and on latitude from $60^{\circ} \mathrm{N}$ (Sweden) to $30^{\circ} \mathrm{N}$ (Egypt) [3]. It is the most common tick species in Germany, and is present in all 16 federal states [1]. One of the main characteristics supporting the wide geographic distribution of this tick species is the low host specificity. More than 300 vertebrate species are described as feeding hosts for I. ricinus ([4] after Bowmann and Nuttall, 2008). It is an exophilic tick species with three different developmental stages, each stage feeding on different hosts to continue the life cycle. Ixodes ricinus is mainly found in deciduous and mixed forests and shrubs but also in urban and peri-urban habitat types [4]. It can transmit a broad spectrum of pathogens to both animals and humans, with the tickborne encephalitis virus (TBEV) and Borrelia burgdorferi sensu lato (s.l.). being among the most relevant disease agents in Europe for public health. Ixodes ricinus is considered the best studied tick species in Germany, and various reports have confirmed its ability to carry multiple pathogens (bacteria, viruses or parasites) [1, 5-10].

Dermacentor reticulatus is the second most commonly encountered tick species in Central Europe after I. ricinus, having a distribution that extends from $9^{\circ} \mathrm{W}$ (Portugal) to $88^{\circ} \mathrm{E}$ (western Siberia) and within the latitude range of $34-60^{\circ} \mathrm{N}$ [11]. The geographic range of this species in Germany indicates that it is widespread in the eastern federal states of Brandenburg, Saxonia, Saxonia-Anhalt and Berlin [1]. The northern location of D. reticulatus in Germany is represented by a site at the Baltic Sea coast in the port of Rostock [11] and there are also indications needing confirmation that its range extends further north, a citizen science project reporting the presence of D. reticulatus on the island of Sylt [12]. Similar to I. ricinus, it is a three-host tick species, and while adults are exophilic ticks, feeding on large mammals (dogs, sheep, goats, horses, cattle, occasionally humans), the larvae and nymphs of $D$. reticulatus are nidicolous, feed mostly on rodents and are rarely collected by flagging [13, 14]. The preferred habitats of this tick species are deciduous and mixed forests, meadows and pastures, requiring moderate humidity levels [14]. Dermacentor reticulatus is a competent vector for several pathogens such as Babesia canis (responsible for canine babesiosis in Europe), Babesia caballi (causing equine babesiosis) [15], Rickettsia raoultii (causative agent of tick-borne lymphadenopathy) or Francisella tularensis (tularaemia) and Coxiella burnetii ( $\mathrm{Q}$ fever agent) [13]. The TBEV has also been detected in D. reticulatus from Germany and this tick species is considered to act as a vector for the virus [16].

The west-east distribution of Haemaphysalis concinna extends from the Spanish Atlantic coast to Kamchatka (Russia) while the latitude range is $28-64^{\circ}$ $\mathrm{N}$ [17]. The northern limit of $H$. concinna in Europe is reported from Germany at $53.30^{\circ} \mathrm{N}$ latitude [18]. In connected water landscapes from Central Europe (such as the Mecklenburg lake plateau in the north-east of Germany or alongside the Danube and Morava rivers), it is considered the third most encountered tick species after $I$. ricinus and D. reticulatus [17]. The occurrence of $H$. concinna in Germany is patchy and a total of 24 known locations have been described [1].

The life cycle of $H$. concinna requires three different hosts (small or medium-sized mammals, birds or reptiles). It is an exophilic tick species that completes its developmental cycle within 3 years $[19,20]$, and it can be found in different habitat types such as deciduous and mixed forests, river valleys, or in close proximity to lakes, in habitats of forest steppes and wet steppes $[17,19]$. A broad variety of known tick-borne pathogens have been detected in this tick species such as $B$. burgdorferi s.l. (causative agent of Lyme borreliosis), $C$. burnetii, F. tularensis, Babesia divergens (responsible for bovine babesiosis), B. canis, or Anaplasma phagocytophilum (human granulocytic anaplasmosis and tickborne fever of ruminants) (reviewed by [17]).

The northern distribution limit of I. ricinus has been advancing northwards in Sweden since the climate began to change significantly in the late 1980s [21]. In addition, the expansion of $D$. reticulatus in Europe is considered a result of climate change alongside other factors such as the increase of deer abundance and the availability of more fallow land due to the EU agricultural policies [22]. It is essential to conduct active monitoring for an accurate determination of the geographic distribution of ticks in order to rightly assess the risk posed by these ectoparasites in different regions. In this study, a collection of questing ticks was conducted to identify the 
composition of tick species and the associated pathogens at different sites near the German Baltic coast, north-east of Germany.

\section{Methods \\ Collection of ticks and species identification}

Questing ticks were collected from five different locations in Western Pomerania, Germany (Fig. 1). Ticks were collected once a month from May until November 2020 by flagging method [23] between 09:00 am and 02:00 pm at four sites represented mainly by grassland and meadows located in the proximity of lakes or forest: Torgelow (TG; 53.643406, 14.034056), Ueckermünde (UM; 53.733800, 14.043847), Holländerei (HN; 53.680698, 14.046079), and Hohe Düne (HD; 54.188678, 12.135170). These locations were selected after they were evaluated as suitable for encountering $D$. reticulatus, which was the target species to collect in this study. One additional site was included (Putzar-PZ; 53.711169, 13.664667) due to the high tick infestation of a dog reported by the owner, and it was visited in October and November 2020. Ticks were further identified to species and developmental stages using morphological keys [24]. After identification, the samples were stored at $-80^{\circ} \mathrm{C}$ until further processing.

\section{Molecular screening \\ DNA and RNA extraction}

Adult ticks were processed individually while larvae and nymphs were pooled at a maximum of 10 ticks per pool. One pool consisted of ticks from the same tick species, location and date. Homogenization of ticks was done as previously described [25] while DNA and RNA extractions were performed from $100 \mu \mathrm{l}$ aliquots by using NucleoMag ${ }^{\circledR}$ VET kit (Macherey-Nagel, Düren, Germany) and the KingFisher ${ }^{\circledR}$ Flex purification system (Thermo Fisher, Darmstadt, Germany), following the manufacturer's instructions. Total DNA and RNA were eluted in $100 \mu \mathrm{l}$ of elution buffer and stored at $-80{ }^{\circ} \mathrm{C}$ until further use.

\section{Polymerase chain reaction (PCR) and nested PCR for tick species identification and pathogen detection}

A total of 59 ticks morphologically identified as I. ricinus ( $n=40$, representing $7.4 \%$ of females, $7.6 \%$ of males and $11.4 \%$ of the pool of nymphs), H. concinna $(n=8)$ and $D$. reticulatus $(n=11)$ were included in a PCR for genetic confirmation of the tick species based on a part of the cytochrome c oxidase subunit I (COX1) gene. PCR was also conducted for all tick samples to detect Babesia/Theileria spp. 18S rRNA gene and Rickettsia spp. gltA gene, while a nested PCR was done to detect Borrelia spp. 16S-23S rRNA intergenic spacer (IGS). PCR for the Rickettsia ompA gene and nested PCR for Rickettsia ompB gene were done only for a part of the samples that tested positive after Rickettsia gltA PCR in the attempt to identify the Rickettsia species: 43 D. reticulatus samples tested for Rickettsia ompA, 57 I. ricinus and 43 D. reticulatus samples tested for Rickettsia ompB. The reactions were performed using the GoTaq ${ }^{\circledR}$ Flexi DNA Polymerase Kit (Promega, Walldorf, Germany) and a C1000 thermal cycler (Bio-Rad Laboratories Inc., Feldkirchen, Germany). The amplification conditions and primer concentrations were followed as stated in the available publications for each target (Table 1). Each reaction included a positive control (DNA from ticks) and a negative control (molecular-grade water). The PCR products were separated on a $1.5 \%$ agarose gel stained with $\mathrm{ROTI}^{\circledR}$-GelStain Red (Carl Roth GmbH, Karlsruhe, Germany), then visualized using the ChemiDoc ${ }^{\mathrm{TM}}$ MP Imaging System (BioRad Laboratories, Hercules, CA, USA).

\section{qPCR for Anaplasma phagocytophilum}

Tick samples were screened for the A. phagocytophilum $m s p 2$ gene using specific primers and probe (Table 1 ). The fluorogenic probe included a 6-carboxyfluorescein (FAM) reporter attached to the $5^{\prime}$ end and a Black Hole Quencher 1 (BHQ1) at the $3^{\prime}$ end. The reaction was performed using $\mathrm{iTaq}^{\mathrm{TM}}$ universal probes supermix (Bio-Rad Laboratories, Inc., Munich, Germany) and CFX-96 RealTime system (Bio-Rad Laboratories, Inc., Munich, Germany). The reaction mix included $10 \mu \mathrm{L}$ of DNA, $12.5 \mu \mathrm{L}$ of iTaq supermix $(2 \times), 900 \mathrm{nM}$ of each primer, $120 \mathrm{nM}$ probe and $1.75 \mu \mathrm{L}$ of nuclease-free water in a total volume of $25 \mu \mathrm{L}$. The initial denaturation step at $95{ }^{\circ} \mathrm{C}$ for 5 min was followed by 40 cycles of denaturation at $95^{\circ} \mathrm{C}$ for $5 \mathrm{~s}$ and annealing/elongation at $60{ }^{\circ} \mathrm{C}$ for $30 \mathrm{~s}$. Each reaction included positive (DNA of positive ticks) and negative (molecular grade water) controls.

\section{$R T$-qPCR for detection of tick-borne encephalitis virus}

Tick RNA samples were screened for TBEV by RT-qPCR targeting the $3^{\prime}$ non-coding region of the TBEV genome with specific primers and probe (Table 1 ). The reactions were done in a final volume of $20 \mu \mathrm{l}$ using the $\mathrm{iTaq}^{\mathrm{TM}} \mathrm{Uni}^{-}$ versal Probes One-Step Kit (Bio-Rad Laboratories, Inc., Munich, Germany). Each assay contained $5 \mu \mathrm{l}$ of RNA, $10 \mu$ iTaq universal probes reaction mix $(2 \times), 400 \mathrm{nM}$ for each forward and reverse primers and $200 \mathrm{nM}$ probe, $0.5 \mu \mathrm{l}$ iScript advanced reverse transcriptase and $2 \mu \mathrm{l}$ of water. Each run included RNA extracted from TBEV Neudoerfl viral stock as positive control and water as negative control. Thermal cycling conditions were as follows: $50^{\circ} \mathrm{C}$ for $10 \mathrm{~min}, 95^{\circ} \mathrm{C}$ for $5 \mathrm{~min}, 45$ cycles at $95^{\circ} \mathrm{C}$ for $15 \mathrm{~s}$ then $60^{\circ} \mathrm{C}$ for $1 \mathrm{~min}$. 


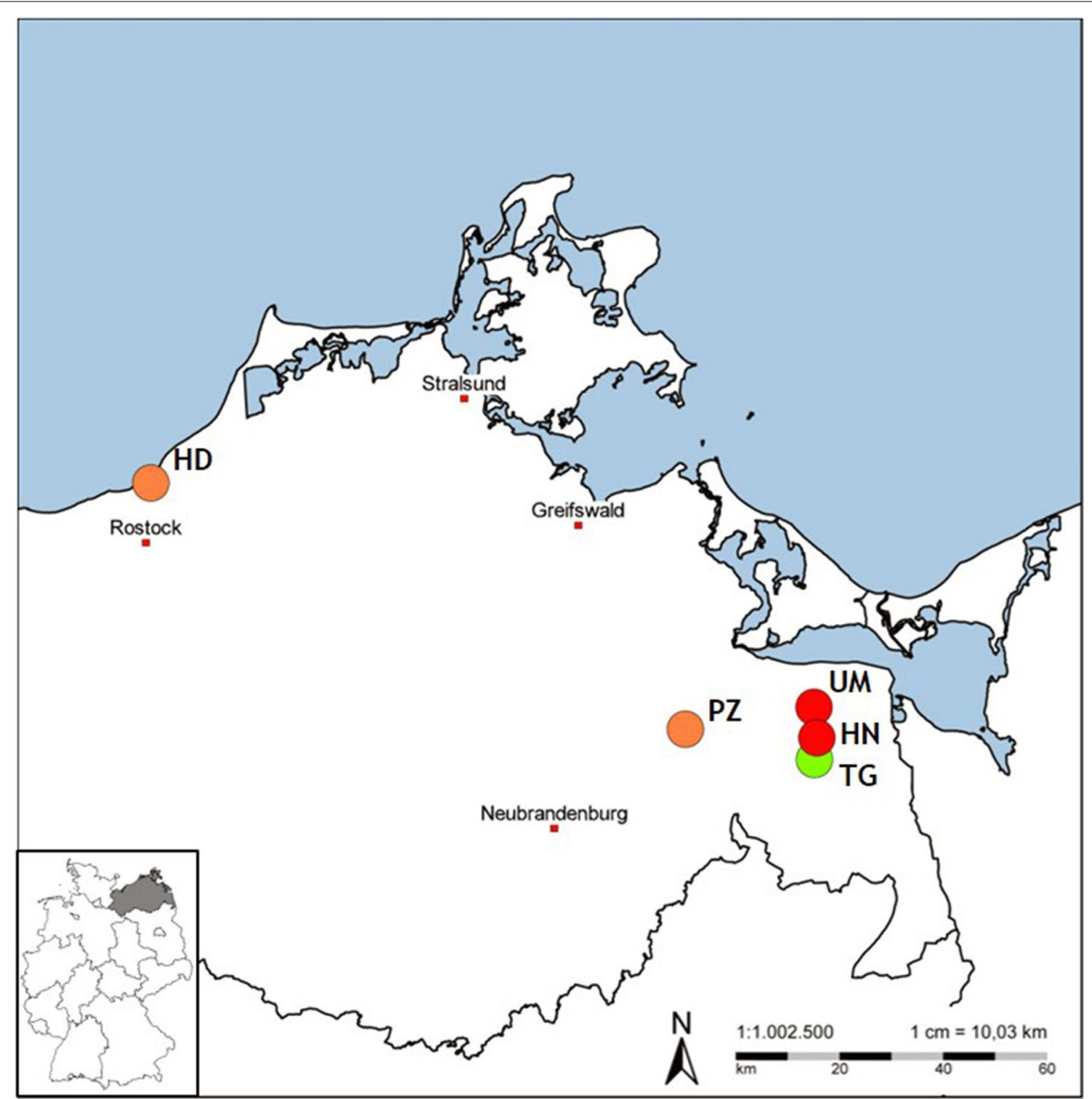

Fig. 1 Sites in north-east of Germany from which questing ticks were collected. HD, Hohe Düne; UM, Ueckermünde; HN, Holländerei; TG, Torgelow; PZ, Putzar. Orange circle: sites where Ixodes ricinus and Dermacentor reticulatus were found; red circle: sites where I. ricinus and Haemaphysalis concinna were observed; green circle: site where I. ricinus, D. reticulatus and H. concinna were observed. The map is copyright free and it was built using Map Explorer version 2.0 2010 , FLI, Wusterhausen

\section{Sequencing the PCR products}

The sequencing strategy included the samples that tested positive for more than one pathogen after the molecular analysis. In addition to those, $13 \mathrm{D}$. reticulatus samples were also sequenced based on the gltA gene to identify the Rickettsia species after testing positive only for this pathogen. In the attempt to clearly determine the Rickettsia species, the 13 samples that were sequenced for Rickettsia spp. gltA and 30 additional D. reticulatus samples were further sequenced based on the ompA and
ompB genes. Two $H$. concinna samples positive only for Babesia/Theileria spp. were also sequenced.

The PCR products were purified with NucleoSEQ ${ }^{\circledR}$ kit (Macherey-Nagel, Düren, Germany), following manufacturer's instructions. After purification, samples were included in a PCR assay, in a $10 \mu \mathrm{L}$ reaction mix: $1 \mu \mathrm{L}$ of $5 \times$ Sequence buffer, $2 \mu \mathrm{L}$ BigDye Ready Reaction Mix (Thermo Fischer, Darmstadt, Germany), $1 \mu \mathrm{L}$ of the reverse primer $(10 \mu \mathrm{M}), 5 \mu \mathrm{L}$ of molecular-grade water and $1 \mu \mathrm{L}$ of the purified PCR product. The thermal 
Table 1 Primers used for tick species confirmation and detection of pathogens in ticks

\begin{tabular}{|c|c|c|c|c|c|}
\hline Target gene & Reaction & Sequence $\left(5^{\prime}-3^{\prime}\right)$ & $\begin{array}{l}\text { Amplicon size } \\
\text { (base pairs) }\end{array}$ & Annealing & Reference \\
\hline \multicolumn{6}{|l|}{ Tick species identification } \\
\hline $\operatorname{COX} 1$ & $P C R$ & $\begin{array}{l}\text { cox1F: GGAACAATATATTTAATTTTTGG } \\
\text { cox1R: ATCTATCCCTACTGTAAATATATG }\end{array}$ & 849 & $55^{\circ} \mathrm{C}$ & {$[51]$} \\
\hline \multicolumn{6}{|l|}{ Babesia/Theileria spp. } \\
\hline 185 rRNA & PCR & $\begin{array}{l}\text { BJ1: GTCTTGTAATTGGAATGATGG } \\
\text { BN2:TAGTTTATGGTTAGGACTACG }\end{array}$ & $411-452$ & $55^{\circ} \mathrm{C}$ & {$[52]$} \\
\hline \multicolumn{6}{|l|}{ Rickettsia spp. } \\
\hline$g l t A$ & PCR & $\begin{array}{l}\text { Rsfg877: GGGGGCCTGCTCACGGCGG } \\
\text { Rfsg1258: ATTGCAAAAAGTACAGTGAACA }\end{array}$ & 381 & $56^{\circ} \mathrm{C}$ & {$[53]$} \\
\hline ompA & PCR & $\begin{array}{l}\text { Rr190.70p: ATGGCGAATATTTCTCCAAAA } \\
\text { Rr190.701n: GTTCCGTTAATGGCAGCATCT }\end{array}$ & 631 & $46^{\circ} \mathrm{C}$ & {$[54]$} \\
\hline ompB & Nested PCR & $\begin{array}{l}\text { PCR1: } \\
\text { ompB-OF: GTAACCGGAAGTAATCGTTTCGTAA } \\
\text { ompB-OR: CTTTATAACCAGCTAAACCACC } \\
\text { Nested PCR: } \\
\text { ompB SFG-IF: GTTTAATACGTGCTGCTAACCAA } \\
\text { ompB SFG/TG-IR: GGTTTGGCCCATATACCATAAGa }\end{array}$ & $\begin{array}{l}489 \\
425\end{array}$ & $\begin{array}{l}54^{\circ} \mathrm{C} \\
56^{\circ} \mathrm{C}\end{array}$ & {$[55]$} \\
\hline \multicolumn{6}{|l|}{ Borrelia spp. } \\
\hline 16S-23S rRNA & Nested PCR & $\begin{array}{l}\text { PCR1: } \\
\text { Bospp-IGS-F: GTATGTTTAGTGAGGGGGGTG } \\
\text { Bospp-IGS-R: GGATCATAGCTCAGGTGGTTAG } \\
\text { Nested PCR: } \\
\text { Bospp-IGS-Fi: AGGGGGGTGAAGTCGTAACAAG } \\
\text { Bospp-IGS-Ri: GTCTGATAAACCTGAGGTCGGA }\end{array}$ & $\begin{array}{l}1007 \\
388-685\end{array}$ & $\begin{array}{l}56^{\circ} \mathrm{C} \\
58^{\circ} \mathrm{C}\end{array}$ & {$[56]$} \\
\hline \multicolumn{6}{|l|}{ Anaplasma phagocytophilum } \\
\hline Major surface protein 2 (Msp2) & $\mathrm{qPCR}$ & $\begin{array}{l}\text { ApMSP2f:TGGAAGGTAGTGTTGGTTATGGTATT } \\
\text { ApMSP2r:TTGGTCTTGAAGCGCTCGTA } \\
\text { ApMSP2p:TGGTGCCAGGGTTGAGCTTGAGATTG }\end{array}$ & 77 & $60^{\circ} \mathrm{C}$ & {$[57]$} \\
\hline \multicolumn{6}{|l|}{ Tick-borne encephalitis virus } \\
\hline 3'non-coding region & RT-qPCR & $\begin{array}{l}\text { F_TBE_1: GGGCGGTTCTTGTTCTCC } \\
\text { R_TBE_1: ACACATCACCTCCTTGTCAGACT } \\
\text { TBE-probe-WT:TGAGCCACCATCACCCAGACACA }\end{array}$ & 67 & $60^{\circ} \mathrm{C}$ & {$[58]$} \\
\hline
\end{tabular}

${ }^{\text {a Primers used in sequencing } \mathrm{PCR}}$

conditions included a denaturation step at $96{ }^{\circ} \mathrm{C}$ for $1 \mathrm{~min}$, then 25 cycles of denaturation at $96{ }^{\circ} \mathrm{C}$ for $10 \mathrm{~s}$, annealing at the specific temperature for each primer for $5 \mathrm{~s}$ (Table 1), elongation at $60{ }^{\circ} \mathrm{C}$ (duration depending on the size of the product). The obtained products were again purified with NucleoSEQ kit (MachereyNagel, Düren, Germany) and $15 \mu \mathrm{L}$ of each purified product were mixed with $15 \mu \mathrm{L}$ of highly deionized (Hi-Di) formamide in a $1.5 \mathrm{ml}$ tube and sequenced at the Institute of Diagnostic Virology, Friedrich-Loeffler-Institut, Germany.

The obtained sequences were viewed and edited in Geneious Prime 2021.0.1 (https://www.geneious.com) and compared with available sequences from GenBank database using BLASTn (http://www.ncbi.nlm.nih.gov. library.vu.edu.au/BLAST/.).

\section{Phylogenetic analysis}

All sequences obtained for the genetic identification of $D$. reticulatus and $H$. concinna based on a part of the COX1 gene were used for the construction of phylogenetic trees together with sequences retrieved from GenBank. The alignment of the sequences was conducted in MEGA $X$ using ClustalW $[26,27]$. Model test was then run in MEGA X for the selection of the suitable model prior to building the phylogenetic trees.

\section{Statistical analysis}

Statistical differences and 95\% confidence intervals (CI) were calculated with GraphPad Prism version 9.0.0 for Windows (GraphPad Software, La Jolla, CA, USA, www. graphpad.com). Ordinary one-way analysis of variance (ANOVA) and Tukey's multiple comparison tests were 
performed on adult tick infection rates for different geographic groups, tick species and pathogens. The unpaired $t$-test with Welch's correction was used to compare the infection levels between two different groups. The results for pathogens detected in pooled samples are expressed as the minimum infection rates (MIR), representing the ratio of the number of positive pools to the total number of analysed ticks, assuming that only one tick from a pool was positive. Differences were considered statistically significant when $P<0.05$.

\section{Results}

\section{Identified tick species and their seasonality}

A total of 1174 questing ticks were collected from May to November 2020 at five different locations from Western Pomerania, Germany. The morphological identification revealed three different tick species. Ixodes ricinus was the most frequently encountered species, with 760 ticks collected ( 524 adults and 236 nymphs) from all five locations. Dermacentor reticulatus was found in three locations (TG, HD and PZ), with 325 adult ticks and one nymph collected. In addition to the above-mentioned tick species, $88 \mathrm{H}$. concinna specimens (15 adults, 62 nymphs and 11 larvae) were found at three collection sites (TG, HN and UM) (Table 2).

The monthly distribution of collected ticks was recorded for I. ricinus from four locations (TG, UM, HN and $\mathrm{HD}$ ), for $D$. reticulatus only from the HD site, and for $H$. concinna from three locations (TG, $\mathrm{UM}$ and $\mathrm{HN}$ ) (Fig. 2).

As shown in Fig. 2, Ixodes ricinus were mostly found in May and June (77.2\% of the total monthly collected ticks) while for $D$. reticulatus the highest number of flagged ticks was in May (49.1\% of the monthly collected D. reticulatus) followed by a second peak in October (26.7\%). Haemaphysalis concinna were mostly found in June (71.6\%) without registering a second peak of occurrence.

BLAST analysis for the valid sequences of I. ricinus (38/40) confirmed the morphological identification of this tick species and had 99.6-100\% identity with reference I. ricinus sequences from GenBank (AY945440 and KF197122). Molecular identification of selected $D$. reticulatus ticks was successful for all samples $(n=11)$ and BLAST analysis showed that the sequences from this study are $100 \%$ identical to D. reticulatus reference sequences (AF132829). The molecular confirmation was done also for $H$. concinna samples and the sequences $(n=8)$ matched $96.6-99.2 \%$ with $H$. concinna sequences from GenBank (KR108858).

The phylogenetic analysis based on the COX1 gene confirmed the morphological and molecular identification of $D$. reticulatus and $H$. concinna, the isolates from this study positioned within the same clades with the reference sequences retrieved from GenBank for the corresponding species (Figs. 3, 4).

\section{Molecular screening of tick-borne pathogens}

Out of the total number of collected ticks, 964 were screened for the selected pathogens: 714 I. ricinus (479 adults and 235 nymphs), 162 D. reticulatus (161 adults and one nymph) and $88 \mathrm{H}$. concinna (15 adults, 62 nymphs and 11 larvae). The RNA samples of all ticks tested negative for the specific RNA of TBEV. Table 3 includes detailed data regarding the prevalence rates for each pathogen identified in different tick species and developmental stages.

Ixodes ricinus ticks tested positive for all other selected pathogens. Borrelia spp. was the most encountered pathogen in I. ricinus adults (49.1\%), showing a significant difference when compared to the infection levels of Rickettsia spp. (14.0\%), Babesia/Theileria spp. (18.2\%) or A. phagocytophilum (1.5\%) $(P<0.001)$. No significant difference was observed between the prevalence rates of Rickettsia spp. and Babesia/Theileria spp. $(P=0.267)$ but both pathogens had a significantly higher prevalence compared to A. phagocytophilum $(P<0.001)$.

From a total of 92 I. ricinus samples positive for Babesia/Theileria after PCR, 70 samples were positive for more than one pathogen and were sequenced. BLASTn analysis identified 62 sequences similar to Babesia microti (MW554613) (57 showed 99.1-100\% similarity and five matched 96.3 to $98.7 \%$ ) while eight samples matched 100\% to Babesia sp. (MW554616).

Out of 263 I. ricinus tick samples positive for Borrelia, 114 were sequenced, resulting in a total of 92 valid sequences. The BLASTn search determined 71 sequences as Borrelia afzelii (MK945792) (98.4-100\% identity), 18 sequences matched $99.3-100 \%$ to both B. afzelii (MK945782) and Babesia spielmanii (JX448323), without a clear distinction between the two genospecies, while the remaining three samples matched $99.9 \%$ to B. burgdorferi sensu stricto (s.s.) (CP077727), 100\% to Borrelia miyamotoi (LC540659) and 99.6\% to Borrelia valaisiana (MK945840), respectively.

Confirmation of Rickettsia species was attempted for 57 samples that showed double or triple infection, out of the total 88 positive $I$. ricinus ticks. In total, 51 valid glt $A$ sequences were obtained. No clear identification of Rickettsia species was possible, 44 samples had $99.4-100 \%$ identity to $R$. helvetica (GenBank accession number: MH618386) and uncultured Rickettsia sp. (KX051405), three sequences showed 99.4 and $100 \%$ identity to $R$. raoultii (MT293352) or Rickettsia sp. (MT424977), two samples had 99.4 and $100 \%$ identity to $R$. monacensis (MH618388) and uncultured Rickettsia (LC060719), and 
Table 2 Questing ticks collected at five locations in Western Pomerania in 2020

\begin{tabular}{|c|c|c|c|c|c|c|c|}
\hline \multirow[t]{2}{*}{ Tick species } & \multirow[t]{2}{*}{ Stage } & \multicolumn{5}{|c|}{ Collection Sites } & \multirow[t]{2}{*}{ Total } \\
\hline & & $\mathrm{HD}$ & TG & $\mathrm{HN}$ & UM & PZ & \\
\hline \multirow[t]{2}{*}{ Ixodes ricinus } & $A$ & 306 & 159 & 3 & 55 & 1 & 524 \\
\hline & $\mathrm{N}$ & 24 & 204 & 1 & 6 & 1 & 236 \\
\hline \multirow[t]{2}{*}{ Dermacentor reticulatus } & A & 116 & 3 & 0 & 0 & 206 & 325 \\
\hline & $\mathrm{N}$ & 0 & 0 & 0 & 0 & 1 & 1 \\
\hline \multirow[t]{3}{*}{ Haemaphysalis concinna } & $A$ & 0 & 8 & 6 & 1 & 0 & 15 \\
\hline & $\mathrm{N}$ & 0 & 61 & 0 & 1 & 0 & 62 \\
\hline & $\mathrm{L}$ & 0 & 11 & 0 & 0 & 0 & 11 \\
\hline
\end{tabular}

$A$ adults, $N$ nymphs, L larvae, HD Hohe Düne, TG Torgelow, HN Holländerei, UM Ueckermünde, PZ Putzar

(a)

Ixodes ricinus

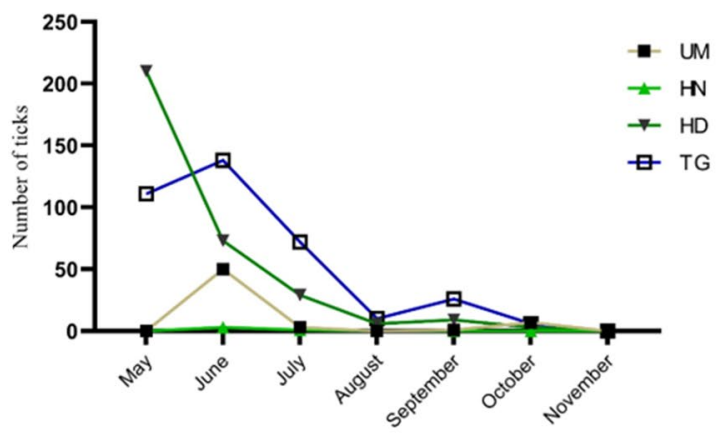

(b)

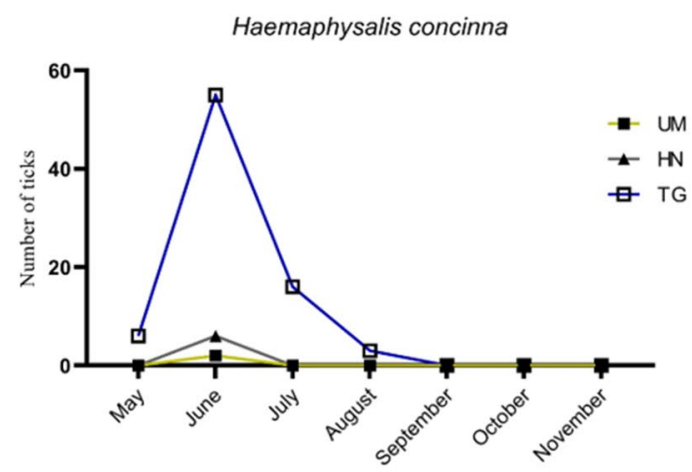

(c) Dermacentor reticulatus

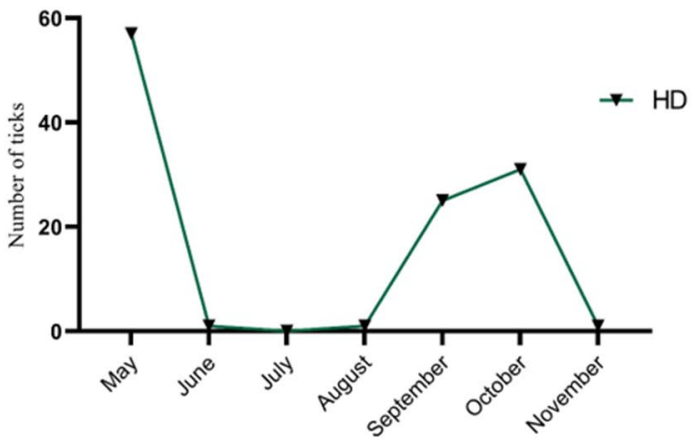

Fig. 2 Monthly distribution of collected ticks. a Ixodes ricinus monthly collected at four different locations: UM, Ueckermünde; HN, Holländerei; HD, Hohe Düne; TG, Torgelow. b Monthly records for Haemaphysalis concinna at three different locations (UM, HN and TG). c Dermacentor reticulatus monthly distribution from $\mathrm{HD}$

two sequences matched $100 \%$ to Candidatus Rickettsia mendelii (KJ882309) and uncultured Rickettsia sp. (AB911109).

Rickettsia ompB sequencing was successful for 49 samples, out of which 44 matched $100 \%$ to $R$. helvetica
(KY951985) and one had $99.7 \%$ similarity to $R$. helvetica (LC461080). For the remaining four samples, clear identification was not possible. Detailed data regarding the results retrieved after BLAST analysis of Rickettsia sequences are available in Additional file 1. 


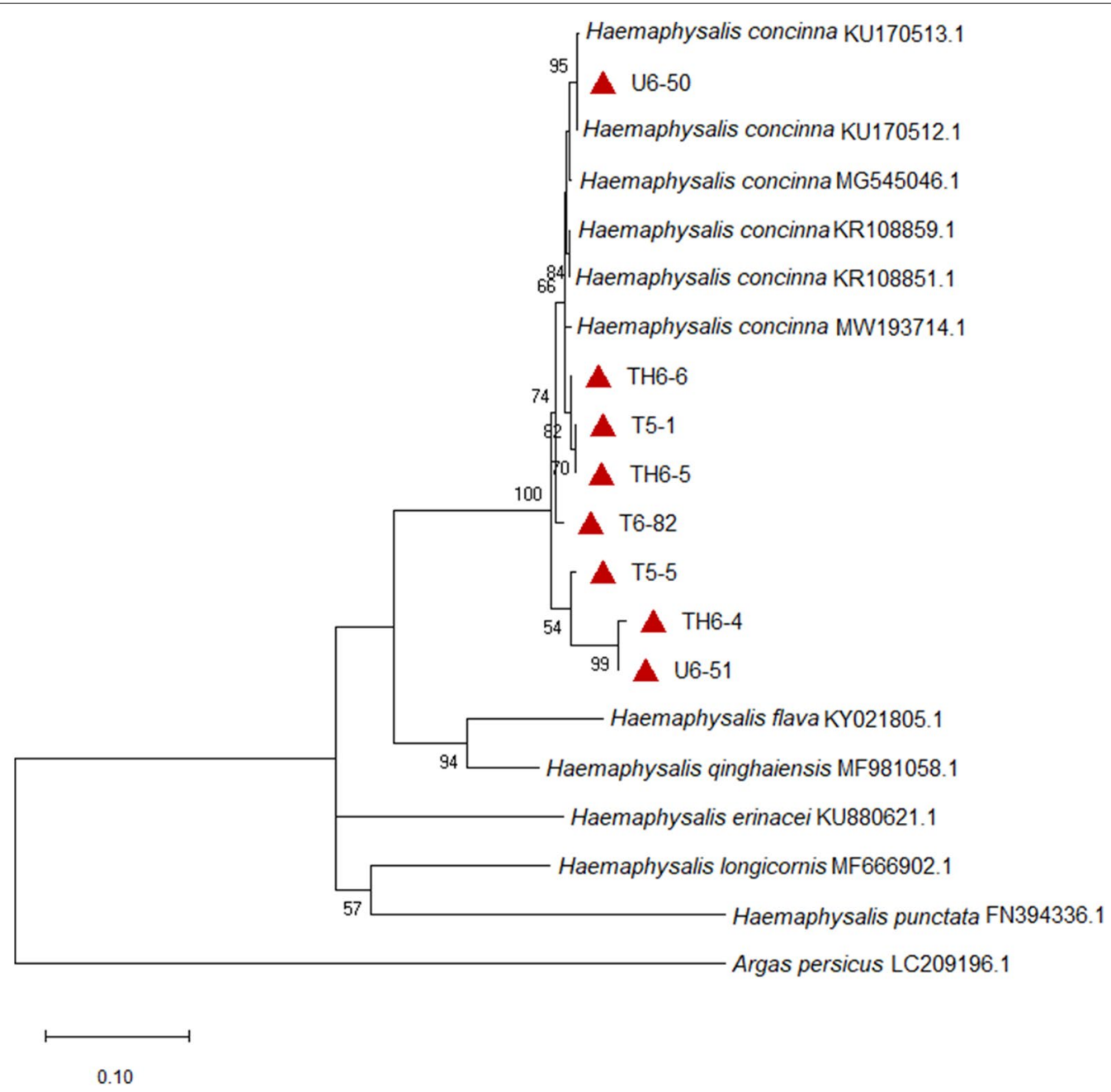

Fig. 3 Phylogenetic tree based on a part of the COX1 gene of Haemaphysalis concinna. The tree was constructed using the maximum likelihood method and Tamura-Nei model [50] with bootstrap support of 1000 replicates. The bootstrap values lower than 50 were omitted from the tree. Argas persicus sequence (GenBank access. no.: LC209196.1) served as outgroup. Entries preceded by a red triangle represent the sequences from the current study: samples from site UM: U6-50 and U6-51; samples from site HN: TH6-4, TH6-5 and TH6-6; samples from site TG: T5-1, T5-5 and T6-82. Low bootstrap values (usually < 50) should be omitted from the tree.

The second most commonly encountered tick species, D. reticulatus, tested positive for Rickettsia spp. and $A$. phagocytophilum. The infection rate of Rickettsia spp. in adults $(82.0 \%$; 133/162) was significantly higher compared to A. phagocytophilum $(0.6 \%)(P<0.001)$. Due to the high prevalence of Rickettsia spp. in D. reticulatus, 13 samples positive only for Rickettsia spp. were initially sequenced based on gltA gene. Sequencing results for gltA gene did not result in a clear identification of Rickettsia species, 2 samples had $100 \%$ identity to Rickettsia helvetica (GenBank accession number: MH618386) and uncultured Rickettsia sp. (KX051405), while 11 samples had $99.6-100 \%$ identity to R. raoultii (MN388798) or uncultured Rickettsia sp. (MN431836). Species confirmation was attempted for the 13 samples and 30 additional ones based on $о т p A$ and $о т p B$ genes. The results retrieved 40 valid sequences of Rickettsia ompA that showed $99.5-100 \%$ ( $n=32$ isolates), $98-99.4 \%(n=7$ isolates) and $97.6 \%$ ( $n=1$ isolate) similarity to several $R$. raoultii sequences (MF166732, KX506737, JN398480) and one entry identified as Rickettsia sp. (AH009131). A distinction between these entries was impossible. In total, 42 Rickettsia ompB sequences were obtained and all showed $100 \%$ identity to different $R$. raoultii isolates from GenBank (HQ232278, DQ365797, KU310593) and to one entry, Candidatus Rickettsia rioja (GQ404431) (Additional file 1).

One $D$. reticulatus tick that showed co-infection with A. phagocytophilum and Rickettsia spp. was sequenced based on the gltA and ompB genes to determine the 


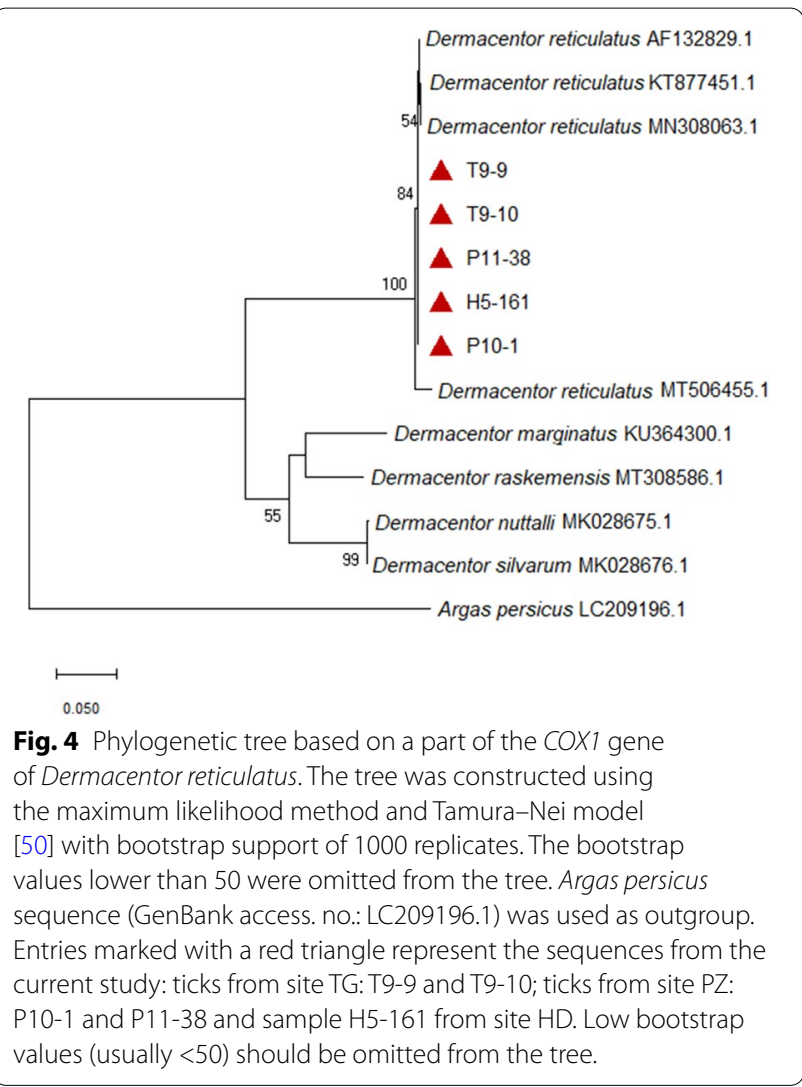

Rickettsia species. The gltA sequence showed 100\% identity to $R$. raoultii (MT293352), Rickettsia sp. (MT424977) or uncultured Rickettsia sp. (MN431836). Based on a part of the ompB gene, the obtained sequence had 100\% similarity to $R$. raoultii (HQ232278) and C. Rickettsia rioja (GQ404431). The PCR reaction for Borrelia spp. and Babesia/Theileria spp. showed unspecific amplification and the samples were considered negative.

Haemaphysalis concinna ticks tested positive for Babesia/Theileria spp., adults showing a prevalence of $13.3 \%$. From the two samples that were sequenced, one matched 100\% to Theileria sp. (MG214907) and Theileria capreoli (MW531681) while the second sample had $99.74 \%$ identity to Babesia sp. (KU550694).

\section{Prevalence of pathogens in ticks from different sites} The PCR for Babesia/Theileria spp. retrieved positive ticks from all locations except the samples collected from HN (Holländerei) (Table 3). When comparing the Babesia/Theileria spp. infection rates of I. ricinus adults according to location, there was a significant difference between ticks from HD and TG $(26.3 \%$ versus 6.3\%; $P<0.001)$ but no statistical difference to samples from UM $(P=0.089)$. Babesia/Theileria spp. were detected in H. concinna ticks collected only from TG (Table 3 ).
Rickettsia was detected in I. ricinus from all locations where this tick species was found. After comparing the infection rates of adult ticks, I. ricinus from TG (21.4\%) showed a significant difference compared to the samples from HD $(10.7 \%)(P=0.006)$. The molecular screening detected high infection rates of $D$. reticulatus for Rickettsia spp. There was no statistical difference between the infection rates in ticks from sites HD and PZ $(P=0.261)$ while all the three $D$. reticulatus adults found at the TG site tested positive for this pathogen (Table 3).

Borrelia was the most encountered pathogen in $I$. ricinus ticks, the statistical analysis in adults indicated a significantly higher prevalence for samples from HD compared to TG (58\% vs $34.6 \%$; $P<0.001)$ but no significance when compared to UM site $(50.9 \%)(P=0.591)$ (Table 3).

Anaplasma phagocytophilum was identified in I. ricinus ticks from sites HD, TG and UM, with no statistically significant differences among adults from different collection sites $(P=0.072)$ (Table 3$)$. Concerning D. reticulatus, only the ticks collected in the HD site were positive for this pathogen, with a $1.4 \%$ prevalence of infection. Overall, all the $H$. concinna ticks tested negative for the presence of $A$. phagocyophilum DNA.

\section{Infection rates of pathogens in different tick species}

There was no significant difference of Babesia/Theileria spp. overall prevalence in I. ricinus adults $(18.2 \%)$ compared to $H$. concinna ticks $(13.3 \%)(P=0.609)$ while the prevalence in $H$. concinna at site TG (25\%) was higher compared to I. ricinus (6.3\%) without a statistical significance $(P=0.292)$ (Table 3$)$.

\section{Co-detection of pathogens}

From the total number of $I$. ricinus ticks that tested positive for at least one putative pathogen, $26.6 \%$ of adults (78/293) and $54.8 \%$ of nymph pools (17/31) showed an association with two or three different pathogens.

In total, 17 different associations were observed in $I$. ricinus: 11 different co-detections of two pathogens and six different associations with three pathogens (Table 4). The most common co-infection in adults was with $B$. microti and B. afzelii (12.3\% of positive ticks), showing a statistically higher infection rate compared to all other co-infections $(P<0.001)$. No significant difference was observed when comparing the co-infection levels with $B$. microti and B. afzelii in I. ricinus adults from sites HD, TG or UM. The second most common co-infection in adults was with $B$. afzelii and $R$. helvetica (4.4\% of positive ticks).

In nymphs, co-detection of $B$. afzelii and $R$. helvetica was observed in $25.8 \%$ positive samples followed by the 


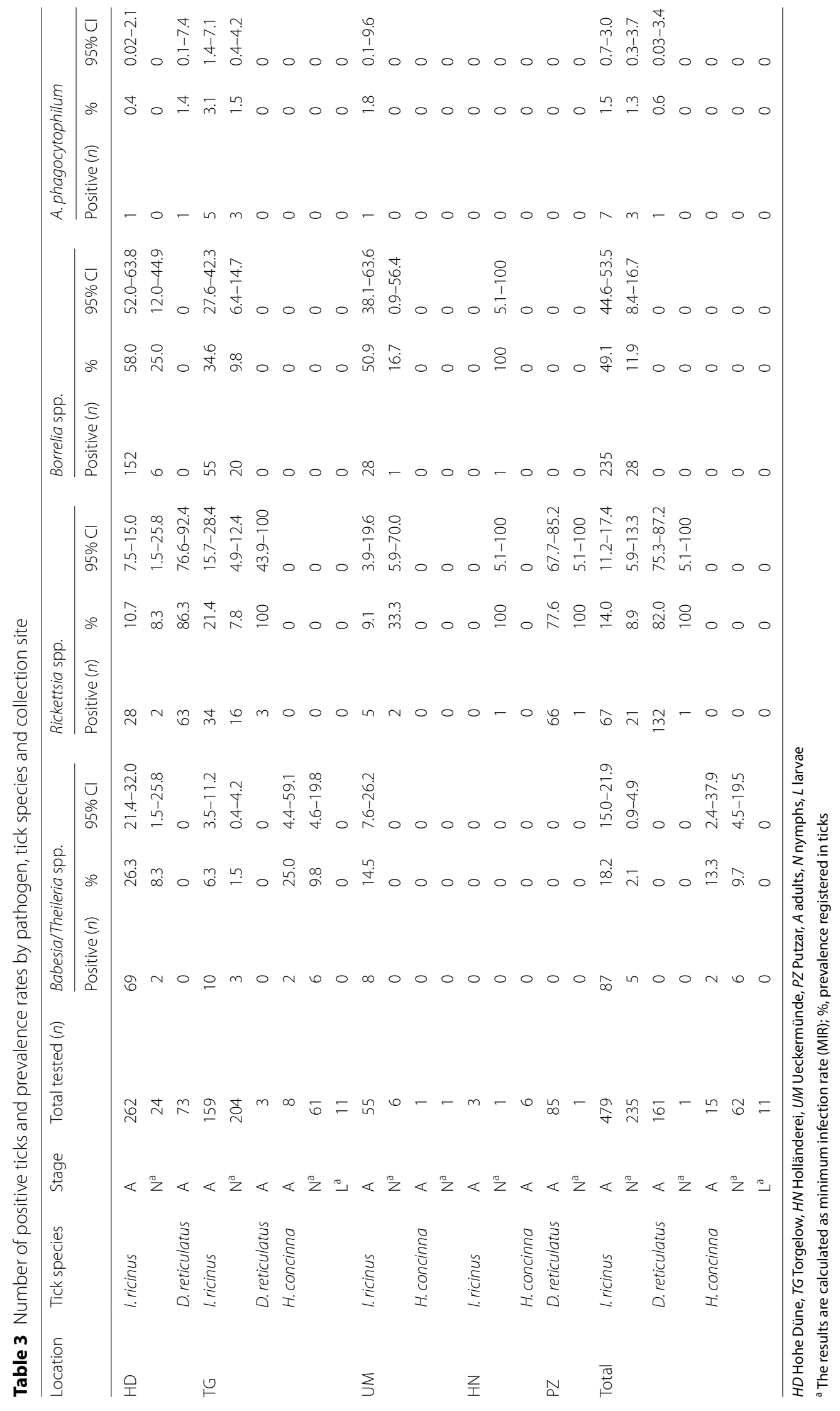


co-detection of B. microti and Borrelia sp. (6.5\%) and Borrelia sp. and R. helvetica (6.5\%).

Co-infection with A. phagocytophilum and Rickettsia spp. was detected in $0.8 \%$ of positive $D$. reticulatus adults $(1 / 132)$ and it was the only co-infection observed in ticks other than I. ricinus. Table 4 contains detailed information on the dual and triple associations of pathogens observed in ticks.

\section{Discussion}

In this study, we conducted a follow-up analysis on the tick population near the Baltic Sea coast to determine the tick species composition and the prevalence rates for some of the most relevant tick-borne pathogens. The results of our previous study, which focused on screening pathogens in I. ricinus only, indicated that questing ticks from Mecklenburg-Western Pomerania can harbour several Borrelia species and that B. miyamotoi infection levels in ticks are at similar levels to other regions in Europe [25]. Considering the current expansion D. reticulatus is undergoing alongside other tick species in Germany and other European countries, we aimed to investigate the presence of this species and the potential sympatric occurrence with other ticks at different sites near the coast in north-east Germany.

Overall, we collected and identified three tick species from the assessed areas. As expected, I. ricinus was the most frequently encountered tick, previously reported as the species with the widest geographic distribution in Germany [1]. Previous reports indicated the sympatric distribution of I. ricinus with Ixodes inopinatus in southern and northern Germany [28, 29]. Ixodes inopinatus was described in 2014 as a new species closely related to I. ricinus [30]. Due to the similar morphological features of $I$. ricinus and I. inopinatus, we conducted molecular identification for a representative batch of the collected I. ricinus ticks and all sequences belonged to this tick species, confirming the initial morphological identification. Further extensive tick collection campaigns should determine whether I. inopinatus is present in Western Pomerania.

Dermacentor reticulatus was found at three collection sites which confirms the presence of this species in north-east Germany. In recent years this species continuously expanded its geographic range in several European countries, Germany included, and it is the second most

Table 4 Co-detection rates observed in positive ticks for at least one pathogen by location, tick species and developmental stage

\begin{tabular}{|c|c|c|c|c|c|c|c|c|c|c|c|c|c|c|c|c|c|c|c|c|}
\hline & \multicolumn{3}{|l|}{$\mathrm{HD}$} & \multicolumn{5}{|l|}{ TG } & \multicolumn{2}{|l|}{ UM } & \multicolumn{2}{|l|}{$\mathrm{HN}$} & \multirow{2}{*}{\multicolumn{2}{|c|}{$\begin{array}{l}\mathrm{PZ} \\
\mathrm{DR}\end{array}$}} & \multicolumn{6}{|l|}{ Total } \\
\hline & \multicolumn{2}{|l|}{$\mathbb{R}$} & \multirow{2}{*}{$\begin{array}{l}\text { DR } \\
\text { A }\end{array}$} & \multicolumn{2}{|l|}{$\mathbb{I R}$} & \multirow{2}{*}{$\begin{array}{l}\text { DR } \\
\text { A }\end{array}$} & \multicolumn{2}{|c|}{$\mathrm{HC}$} & \multirow{2}{*}{$\begin{array}{l}\mathbb{R} \\
\mathrm{A}\end{array}$} & \multirow{2}{*}{$\begin{array}{l}\mathrm{HC} \\
\mathrm{N}\end{array}$} & \multirow{2}{*}{$\begin{array}{l}\text { IR } \\
N\end{array}$} & \multirow{2}{*}{$\begin{array}{l}\mathrm{HC} \\
\mathrm{A}\end{array}$} & & & \multicolumn{2}{|l|}{$\mathbb{I R}$} & \multicolumn{2}{|l|}{ DR } & \multicolumn{2}{|c|}{$\mathrm{HC}$} \\
\hline & A & $\mathrm{N}$ & & A & $\mathrm{N}$ & & A & $N$ & & & & & A & $\mathrm{N}$ & A & $N$ & A & $N$ & $A$ & N \\
\hline Total positive ticks & 185 & 6 & 63 & 75 & 21 & 3 & 6 & 8 & 33 & 3 & 1 & 5 & 66 & 1 & 293 & 31 & 132 & 1 & 11 & 8 \\
\hline B. microti + B. afzelii & 13.0 & 0 & 0 & 8.0 & 4.8 & 0 & 0 & 0 & 18.2 & 0 & 0 & 0 & 0 & 0 & 12.3 & 3.2 & 0 & 0 & 0 & 0 \\
\hline B. microti+Borrelia sp. & 5.4 & 33.3 & 0 & 0 & 0 & 0 & 0 & 0 & 0 & 0 & 0 & 0 & 0 & 0 & 3.4 & 6.5 & 0 & 0 & 0 & 0 \\
\hline Babesia sp. + B. afzelii & 0.5 & 0 & 0 & 0 & 4.8 & 0 & 0 & 0 & 6.1 & 0 & 0 & 0 & 0 & 0 & 1.0 & 3.2 & 0 & 0 & 0 & 0 \\
\hline Babesia sp. + Borrelia sp. & 1.1 & 0 & 0 & 0 & 0 & 0 & 0 & 0 & 0 & 0 & 0 & 0 & 0 & 0 & 0.7 & 0 & 0 & 0 & 0 & 0 \\
\hline B. microti + R. helvetica & 1.1 & 0 & 0 & 0 & 0 & 0 & 0 & 0 & 0 & 0 & 0 & 0 & 0 & 0 & 0.7 & 0 & 0 & 0 & 0 & 0 \\
\hline Babesia sp. $+R$. helvetica & 0.5 & 0 & 0 & 0 & 4.8 & 0 & 0 & 0 & 0 & 0 & 0 & 0 & 0 & 0 & 0.7 & 0 & 0 & 0 & 0 & 0 \\
\hline Babesia sp. + Rickettsia sp. & 0.5 & 0 & 0 & 0 & 0 & 0 & 0 & 0 & 0 & 0 & 0 & 0 & 0 & 0 & 0.3 & 0 & 0 & 0 & 0 & 0 \\
\hline B. afzelii + R. helvetica & 3.8 & 0 & 0 & 8 & 33.3 & 0 & 0 & 0 & 0 & 0 & 100 & 0 & 0 & 0 & 4.4 & 25.8 & 0 & 0 & 0 & 0 \\
\hline B. valaisiana $+R$. helvetica & 0.5 & 0 & 0 & 0 & 0 & 0 & 0 & 0 & 0 & 0 & 0 & 0 & 0 & 0 & 0.3 & 0 & 0 & 0 & 0 & 0 \\
\hline Borrelia spp. $+R$. helvetica & 0.5 & 16.7 & 0 & 0 & 4.8 & 0 & 0 & 0 & 0 & 0 & 0 & 0 & 0 & 0 & 0.3 & 6.5 & 0 & 0 & 0 & 0 \\
\hline A. phagocytophilum + R. helvetica & 0 & 0 & 0 & 2.7 & 0 & 0 & 0 & 0 & 0 & 0 & 0 & 0 & 0 & 0 & 0.7 & 0 & 0 & 0 & 0 & 0 \\
\hline A. phagocytophilum + Rickettsia sp. & 0 & 0 & 1.6 & 0 & 0 & 0 & 0 & 0 & 0 & 0 & 0 & 0 & 0 & 0 & 0 & 0 & 0.8 & 0 & 0 & 0 \\
\hline B. microti + B. afzelii + R. helvetica & 0.5 & 0 & 0 & 1.3 & 4.8 & 0 & 0 & 0 & 0 & 0 & 0 & 0 & 0 & 0 & 0.7 & 3.2 & 0 & 0 & 0 & 0 \\
\hline B. microti + B. afzelii + R. monacensis & 0.5 & 0 & 0 & 0 & 0 & 0 & 0 & 0 & 0 & 0 & 0 & 0 & 0 & 0 & 0.3 & 0 & 0 & 0 & 0 & 0 \\
\hline B. microti + B. afzelii + Rickettsia sp. & 0 & 0 & 0 & 1.3 & 0 & 0 & 0 & 0 & 0 & 0 & 0 & 0 & 0 & 0 & 0.3 & 0 & 0 & 0 & 0 & 0 \\
\hline B. microti+Borrelia sp. + R. helvetica & 0.5 & 0 & 0 & 0 & 0 & 0 & 0 & 0 & 0 & 0 & 0 & 0 & 0 & 0 & 0.3 & 0 & 0 & 0 & 0 & 0 \\
\hline B. microti + Borrelia sp. + Rickettsia sp. & 0.5 & 0 & 0 & 0 & 0 & 0 & 0 & 0 & 0 & 0 & 0 & 0 & 0 & 0 & 0.3 & 0 & 0 & 0 & 0 & 0 \\
\hline Babesia sp. + B. afzelii + R. helvetica & 0 & 0 & 0 & 0 & 4.8 & 0 & 0 & 0 & 0 & 0 & 0 & 0 & 0 & 0 & 0 & 3.2 & 0 & 0 & 0 & 0 \\
\hline Total co-infections & 29.2 & 50 & 1.6 & 21.3 & 61.9 & 0 & 0 & 0 & 24.2 & 0 & 100 & 0 & 0 & 0 & 26.6 & 54.8 & 0.8 & 0 & 0 & 0 \\
\hline
\end{tabular}

HD Hohe Düne, TG Torgelow, HN Holländerei, UM Ueckermünde, PZ Putzar, IR Ixodes ricinus, DR Dermacentor reticulatus, HC Haemaphysalis concinna, $A$ adults, $N$ nymphs 
widespread questing tick on the continent after I. ricinus [31]. Climate change has been incriminated as the dominant factor for the range expansion of $D$. reticulatus, nevertheless, the importance of other contributing factors like changes in land use, availability of wildlife hosts, and intense travel of humans and their pets should not be neglected [13].

Collecting D. reticulatus from the environment in $\mathrm{HD}$ site, very close to the German Baltic coast (Fig. 1), confirms the northward expansion of this species in Germany and the previous documentation of this tick in the port of Rostock $\left(12.14^{\circ} \mathrm{E} 54.15^{\circ} \mathrm{N}\right)$ [11]. A recent publication reported the presence of $D$. reticulatus further north, on the island of Sylt. The observation was made during a citizen science, still, further research is needed to confirm this finding [12].

Haemaphysalis concinna was the third most prevalent questing tick species collected in this study. The observation of $H$. concinna at site UM (Fig. 1) further expands the reported northern distribution limit of this species in Europe. The previously known limit from Germany was reported in 2016 at the Seedorf military training area $\left(9.26^{\circ} \mathrm{E} / 53.30^{\circ} \mathrm{N}\right)$ [18]. In this study, H. concinna was collected from sites near the Mecklenburg lake plateau, an area that was described as suitable to maintain $H$. concinna tick populations, and where this tick is considered the third most common species after I. ricinus and D. reticulatus [17]. Information regarding the circulation of $H$. concinna near the German Baltic coast is available since 1960, with published data indicating several specimens collected in 1958 from Capreolus capreolus (L.) deer at several locations near Greifswald [32]. Our observations confirm the presence of the $H$. concinna population in the north-east of Germany by providing the exact geographical locations where this species occurs.

Ixodes ricinus showed a main peak of occurrence in May-June while $D$. reticulatus was most active in May, followed by a second lower peak in September for $I$. ricinus and September-October for D. reticulatus. The occurrence of $H$. concinna suggested only one peak of activity in June. The monthly distribution of occurrence is in line with the known seasonal activity of all three species and could be of use in predicting the seasonality of tick-transmitted diseases [33].

The morphological identification of $D$. reticulatus and $H$. concinna was molecularly confirmed based on the COX1 gene that proved to be suitable in identifying ticks at species level. The phylogenetic analysis further supported the morphological and genetic species identification, the sequences from this work clustered within the same clade with reference sequences corresponding to
D. reticulatus and $H$. concinna, respectively, having also good bootstrap support (Figs. 3, 4).

Using molecular methods, ticks were screened to determine the infection rates for some of the most common tick-borne pathogens, using species-specific and generic primers. All samples tested negative for TBEV. Even though there have been recent reports of TBEV RNA detection in ticks [34] and anti-TBEV antibodies in animals $[35,36]$ from Mecklenburg-Western Pomerania, the results of this study confirm the low risk classification of this region for TBEV. Nevertheless, the northward expansion of ticks, the land use changes that facilitate movement of virus reservoir hosts, and climate change are factors that could facilitate the range expansion of TBEV towards the northern regions of Germany.

Ixodes ricinus adults and nymphs were positive for all other analysed pathogens: Babesia/Theileria spp., Rickettsia spp., Borrelia spp. and A. phagocytophilum. These results highlight the involvement of this tick species in causing health problems of public and veterinary concern.

The Babesia/Theileria spp. prevalence in questing $I$. ricinus adults in our study (18.2\%) was higher compared to the observed infection levels in I. ricinus from different geographical areas in Germany that ranged between $0.4 \%$ and $10.7 \%$ [10]. In addition, 70 out of 92 total Babesia positive samples were sequenced and most of the isolates $(n=62)$ matched B. microti, the protozoan blood parasite responsible for human babesiosis [37]. These results indicate that there is a significant risk of acquiring this protozoan after a tick bite at the sites selected for this work. Ixodes ricinus ticks collected at site HD near Rostock showed the highest infection rate for Babesia spp. (26.3\% in adults and MIR of $8.3 \%$ in nymphs), and the transmission of the pathogen can be facilitated also by the high human activity in the vicinity of this collection site.

The observed Rickettsia spp. infection rate in I. ricinus adults in our study (14\%) is higher when compared to data available from questing ticks collected near the German Baltic coast (8.5\%) [38], which can suggest an increase over time of the tick infection rates with Rickettsia spp. Ticks simultaneously act as vectors and reservoir hosts for Rickettsia, and the efficient transovarial transmission in I. ricinus ticks observed under laboratory settings might contribute to the maintenance of the microorganism in tick populations [39]. In the sequenced samples, $R$. helvetica was the dominant species (in 45 out of 49 valid sequences). This species belongs to the spotted fever group (SFG) rickettsiae and it is reported as a pathogenic agent in humans transmitted mainly by Ixodes ticks [40]. The current study confirms the presence of this 
pathogen in questing ticks from north-east Germany, yet further analyses are required to provide a clear estimation of $R$. helvetica prevalence in tick populations from this region.

Borrelia was the most common pathogen detected in the assessed ticks (49.1\% of adult ticks and MIR of $11.9 \%$ in nymphs) showing a higher prevalence compared to our previous study $(12.1 \%$ in adults and MIR of $3.3 \%$ in nymphs) [25]. The infection levels of I. ricinus ticks for Borrelia spp. are also high when compared to other studies in questing ticks from Germany. High infection rates with $B$. burgdorferi s.l. were also reported from southern Germany (up to $36.2 \%$ ) [41]. The primer pairs used in this study to detect Borrelia spp. are also amplifying the 16S-23S rRNA IGS sequence of B. miyamotoi relapsing fever agent, and since not all samples were sequenced, the herein results regarding the prevalence of $B$. burgdorferi s.l. should be interpreted with caution. On the other hand, based on the B. miyamotoi infection rates found in I. ricinus ticks from Europe, ranging from $0.4 \%$ in Estonia to $3.5 \%$ in France and Germany [42-44], we can expect a high prevalence of B. burgdorferi s.l. in I. ricinus ticks from this study. Borrelia spp. showed high prevalence in I. ricinus ticks from sites HD (58\% in adults and MIR of $25 \%$ in nymphs) and UM (50.9\% in adults and MIR of $16.7 \%$ in nymphs) (Table 3 ). These sites are located in peri-urban areas that represent high-risk locations for public health due to increased tick-human contact.

The observed prevalence of $A$. phagocytophilum in $I$. ricinus ticks from this study (1.5\% in adults and MIR of $1.3 \%$ in nymphs) is comparable to other published data from northern Germany: 1\% near the German Baltic Coast [38], 3.6\% in Hamburg [45], and 3.8\% overall prevalence for a 10-year interval in Hanover [39]. Supplementary research on a larger scale is needed to determine the prevalence of this pathogen in tick populations and furthermore to identify the circulating A. phagocytophilum variants which will facilitate the proper evaluation of the risk posed by this tick-borne pathogen to human and animal health.

Molecular screening of D. reticulatus ticks for tickborne pathogens enabled the detection of high infection levels with Rickettsia spp. Overall, 82\% (132/161) of the adults tested positive with a homogenous distribution of the prevalence among different collection sites. In addition, approximately one third of the positive samples were sequenced for $o m p B$ gene $(42 / 132)$ and matched to $R$. raoultii and $C$. Rickettsia rioja. Both of these bacteria are described as causative agents of Dermacentor-borne necrosis erythema and lymphadenopathy (DEBONEL) or tick-borne lymphadenopathy (TIBOLA) in humans
$[13,46]$. According to these results, the sites at which $D$. reticulatus ticks were observed are locations where people could potentially acquire SFG Rickettsia following a tick bite.

From the range of screened tick-borne pathogens, $H$. concinna ticks tested positive only for Babesia/Theileria spp., with sequences that matched Theileria sp. or $T$. capreoli and Babesia sp. Previous studies have reported detection of piroplasmids of the genus Theileria in questing $H$. concinna from Austria [47] or Hungary [48], and Babesia in H. concinna larvae collected from rodents in Slovakia [49], to which the isolate from our study was closely related. These results suggest a potential role of this tick species as vector for Theileria and Babesia in Central Europe. Vector competence studies would be valuable in understanding the role of $H$. concinna as vector for pathogenic Theileria and Babesia species.

Co-detection of pathogens was mostly observed in $I$. ricinus ticks; from the adults and nymph pools positive for at least one agent, $26.6 \%$ and $54.8 \%$ of the respective adults and nymph pools registered association of two or three different pathogens. The results from the pools of nymphs need to be treated with care since they can express an overestimated association of pathogens. Nevertheless, the high number of I. ricinus ticks positive for several pathogens confirms the ability of this species to carry a broad range of pathogens, and exhaustive work is needed to fill the gap on the knowledge in regard to the relationship between pathogens (positive or negative interactions) within the same tick.

\section{Conclusions}

In conclusion, the results of our study represent new data that confirm an expansion of the northern distribution limit of $D$. reticulatus and $H$. concinna. We also confirm the existence of suitable habitats for the sympatric occurrence of I. ricinus, D. reticulatus, and H. concinna near the German Baltic coast, by providing exact geographic locations where these ticks were encountered. The high infection levels of I. ricinus with Babesia/Theileria spp., Rickettsia spp. and Borrelia spp., and of D. reticulatus with Rickettsia spp. at periurban areas suggest a high risk for public health that is facilitated also by a potentially increased tick-human contact. We have also confirmed the ability of I. ricinus to carry several pathogens and provided detailed data of the infection levels at each location, data that could be useful in assessing the risk of acquiring a pathogen following a tick bite. 


\section{Abbreviations}

MIR: Minimum infection rate; HD: Hohe Düne; UM: Ueckermünde; HN: Holländerei; TG: Torgelow; PZ: Putzar; COX1: Cytochrome c oxidase subunit I; $18 S$ rRNA: 18 Svedberg ribosomal ribonucleic acid; gltA: Citrate synthase gene; ompA: Outer membrane protein A; ompB: Outer membrane protein B; IGS: Intergenic spacer; msp2: Major surface protein 2; BLAST: Basic local alignment search tool; Cl: Confidence interval.

\section{Supplementary Information}

The online version contains supplementary material available at https://doi. org/10.1186/s13071-022-05173-2.

Additional file 1: Table S1. BLAST results retrieved for Rickettsia gltA ompA and $o m p B$ according to tick species and collection site.

\section{Acknowledgements}

We thank Dr. Gerhard Dobler (Bundeswehr Institute of Microbiology, German Center for Infection Research) and Dr. Kerstin Wernike (Institute of Diagnostic Virology, Friedrich-Loeffler-Institut) for kindly providing the positive control for tick-borne encephalitis RT-qPCR reaction. We are also grateful to Dr. Susanne Fischer and Ulrike Neumann for their help during the collection of ticks.

\section{Authors' contributions}

CS and CR organized and designed the study. CR and OT organized and performed the fieldwork. CR and OT performed the analysis of ticks in the laboratory. CR and CS analysed the data and drafted the manuscript. CS critically reviewed the manuscript. All authors read and approved the final manuscript.

\section{Funding}

Open Access funding enabled and organized by Projekt DEAL. Not applicable.

\section{Availability of data and materials}

All data generated or analysed during this study are included in this published article. Newly generated sequences were submitted to the GenBank database and received the following accession numbers: Babesia spp.: OL549321OL549398; Rickettsia spp.: OL549399-OL549443; Borrelia spp.: OL701405OL701478; tick species: OL639104-OL639118.

\section{Declarations}

Ethics approval and consent to participate Not applicable.

\section{Consent for publication}

Not applicable.

\section{Competing interests}

The authors declare that they have no competing interests.

\section{Author details}

${ }^{1}$ Institute of Infectology, Friedrich-Loeffler-Institut, Suedufer 10, 17493 Greifswald-Insel Riems, Germany. ${ }^{2}$ Department of Biology, University of Greifswald, Domstraße 11, 17489 Greifswald, Germany.

Received: 15 October 2021 Accepted: 21 January 2022

Published online: 22 February 2022

\section{References}

1. Rubel F, Brugger K, Chitimia-Dobler L, Dautel H, Meyer-Kayser E, Kahl O. Atlas of ticks (Acari: Argasidae, Ixodidae) in Germany. Exp Appl Acarol. 2021;84(1):183-214. https://doi.org/10.1007/s10493-021-00619-1.

2. Chitimia-Dobler L, Schaper S, Riess R, Bitterwolf K, Frangoulidis D, Bestehorn M, et al. Imported Hyalomma ticks in Germany in 2018. Parasit Vectors. 2019;12(1):134. https://doi.org/10.1186/s13071-019-3380-4.
3. Randolph SE, Green RM, Hoodless AN, Peacey MF. An empirical quantitative framework for the seasonal population dynamics of the tick Ixodes ricinus. Int J Parasitol. 2002;32(8):979-89. https://doi.org/10.1016/s00207519(02)00030-9.

4. Rizzoli A, Silaghi C, Obiegala A, Rudolf I, Hubalek Z, Foldvari G, et al. Ixodes ricinus and its transmitted pathogens in urban and peri-urban areas in Europe: new hazards and relevance for public health. Front Public Health. 2014;2:251. https://doi.org/10.3389/fpubh.2014.00251.

5. Blazejak K, Raulf MK, Janecek E, Jordan D, Fingerle V, Strube C. Shifts in Borrelia burgdorferi (s.l.) geno-species infections in Ixodes ricinus over a 10-year surveillance period in the city of Hanover (Germany) and Borrelia miyamotoi-specific Reverse Line Blot detection. Parasit Vectors. 2018;11(1):304. https://doi.org/10.1186/s13071-018-2882-9.

6. Overzier E, Pfister K, Thiel C, Herb I, Mahling M, Silaghi C. Anaplasma phagocytophilum in questing Ixodes ricinus ticks: comparison of prevalences and partial 16S rRNA gene variants in urban, pasture, and natural habitats. Appl Environ Microbiol. 2013;79(5):1730-4. https://doi. org/10.1128/AEM.03300-12.

7. Klaus C, Hoffmann B, Hering U, Mielke B, Sachse K, Beer M, et al. Tick-borne encephalitis (TBE) virus prevalence and virus genome characterization in field-collected ticks (Ixodes ricinus) from risk, nonrisk and former risk areas of TBE, and in ticks removed from humans in Germany. Clin Microbiol Infect. 2010;16(3):238-44. https://doi.org/10. 1111/j.1469-0691.2009.02764.x.

8. Zubrikova D, Wittmann M, Honig V, Svec P, Vichova B, Essbauer S, et al. Prevalence of tick-borne encephalitis virus and Borrelia burgdorferi sensu lato in Ixodes ricinus ticks in Lower Bavaria and Upper Palatinate. Germany Ticks Tick Borne Dis. 2020;3:101375. https://doi.org/10.1016/j. ttbdis.2020.101375.

9. May K, Jordan D, Fingerle V, Strube C. Borrelia burgdorferi sensu lato and co-infections with Anaplasma phagocytophilum and Rickettsia spp. in Ixodes ricinus in Hamburg, Germany. Med Vet Entomol. 2015;4:425-9. https://doi.org/10.1111/mve.12125.

10. Silaghi C, Woll D, Hamel D, Pfister K, Mahling M, Pfeffer M. Babesia spp. and Anaplasma phagocytophilum in questing ticks, ticks parasitizing rodents and the parasitized rodents-analyzing the host-pathogen-vector interface in a metropolitan area. Parasit Vectors. 2012;5:191. https:// doi.org/10.1186/1756-3305-5-191.

11. Rubel F, Brugger K, Belova OA, Kholodilov IS, Didyk YM, Kurzrock L, et al. Vectors of disease at the northern distribution limit of the genus Dermacentor in Eurasia: D. reticulatus and D. silvarum. Exp Appl Acarol. 2020;1:95-123. https://doi.org/10.1007/s10493-020-00533-y.

12. Drehmann M, Springer A, Lindau A, Fachet K, Mai S, Thoma D, et al. The spatial distribution of Dermacentor ticks (Ixodidae) in Germany-evidence of a continuing spread of Dermacentor reticulatus. Front Vet Sci. 2020;7: 578220. https://doi.org/10.3389/fvets.2020.578220.

13. Foldvari G, Siroky P, Szekeres S, Majoros G, Sprong H. Dermacentor reticulatus: a vector on the rise. Parasit Vectors. 2016;1:314. https://doi. org/10.1186/s13071-016-1599-x.

14. Nosek J. The ecology and public health importance of Dermacentor marginatus and D. reticulatus ticks in Central Europe. Folia Parasitol (Praha). 1972;19:93-102.

15. Gray JS, Estrada-Pena A, Zintl A. Vectors of Babesiosis. Annu Rev Entomol. 2019;64:149-65. https://doi.org/10.1146/annur ev-ento-011118-111932.

16. Chitimia-Dobler L, Lemhofer G, Krol N, Bestehorn M, Dobler G, Pfeffer $M$. Repeated isolation of tick-borne encephalitis virus from adult Dermacentor reticulatus ticks in an endemic area in Germany. Parasit Vectors. 2019;1:90. https://doi.org/10.1186/s13071-019-3346-6.

17. Rubel F, Brugger K, Walter M, Vogelgesang JR, Didyk YM, Fu S, et al. Geographical distribution, climate adaptation and vector competence of the Eurasian hard tick Haemaphysalis concinna. Ticks Tick Borne Dis. 2018;9(5):1080-9. https://doi.org/10.1016/j.ttbdis.2018.04.002.

18. Faulde MK, Rutenfranz M, Hepke J, Rogge M, Gorner A, Keth A. Human tick infestation pattern, tick-bite rate, and associated Borrelia burgdorferi s.l. infection risk during occupational tick exposure at the Seedorf military training area, northwestern Germany. Ticks Tick Borne Dis. 2014;5(5):594-9. https://doi.org/10.1016/j.ttbdis.2014.04.009.

19. Nosek J. The ecology, bionomics and behaviour of Haemaphysalis (Haemaphysalis) concinna tick. Z Parasitenkd. 1971;36(3):233-41. https://doi.org/10.1007/BF00348561. 
20. Kiewra D, Czulowska A, Dyczko D, Zielinski R, Plewa-Tutaj K. First record of Haemaphysalis concinna (Acari: Ixodidae) in Lower Silesia. SW Poland Exp Appl Acarol. 2019;77(3):449-54. https://doi.org/10.1007/ s10493-019-00344-W.

21. Talleklint L, Jaenson TG. Increasing geographical distribution and density of Ixodes ricinus (Acari: Ixodidae) in central and northern Sweden. J Med Entomol. 1998;35(4):521-6. https://doi.org/10.1093/jmedent/35.4. 521.

22. Gray JS, Dautel H, Estrada-Pena A, Kahl O, Lindgren E. Effects of climate change on ticks and tick-borne diseases in Europe. Interdiscip Perspect Infect Dis. 2009;2009: 593232. https://doi.org/10.1155/2009/593232.

23. Dantas-Torres F, Lia RP, Capelli G, Otranto D. Efficiency of flagging and dragging for tick collection. Exp Appl Acarol. 2013;61(1):119-27. https:// doi.org/10.1007/s10493-013-9671-0.

24. Estrada-Peña A. Ticks of domestic animals in the Mediterranean region: a guide to identification of species. University of Zaragoza; 2004.

25. Raileanu C, Tauchmann O, Vasic A, Wohnke E, Silaghi C. Borrelia miyamotoi and Borrelia burgdorferi (sensu lato) identification and survey of tickborne encephalitis virus in ticks from north-eastern Germany. Parasite Vector. 2020;13(1). ARTN 106. https://doi.org/10.1186/s13071-020-3969-7.

26. Kumar S, Stecher G, Knyaz M, Li C, Koichiro T. Mol Biol Evol 2018;35

27. Thompson JD, Higgins DG, TG Gibson. Nucleic Acids Res 1994;22.

28. Chitimia-Dobler L, Riess R, Kahl O, Wolfel S, Dobler G, Nava S, et al. Ixodes inopinatus_occurring also outside the Mediterranean region. Ticks Tick Borne Dis. 2018;9(2):196-200. https://doi.org/10.1016/j.ttbdis.2017.09.004.

29. Hauck D, Springer A, Pachnicke S, Schunack B, Fingerle V, Strube C. Ixodes inopinatus in northern Germany: occurrence and potential vector role for Borrelia spp., Rickettsia spp, and Anaplasma phagocytophilum in comparison with /xodes ricinus. Parasitol Res. 2019;118(12):3205-16. https://doi. org/10.1007/s00436-019-06506-4.

30. Estrada-Pena A, Nava S, Petney T. Description of all the stages of Ixodes inopinatus n. sp. (Acari: Ixodidae). Ticks Tick-Borne Dis. 2014;5:734-43. https://doi.org/10.1016/j.ttbdis.2014.05.003.

31. Rubel F, Brugger K, Monazahian M, Habedank B, Dautel H, Leverenz S, et al. The first German map of georeferenced ixodid tick locations. Parasit Vectors. 2014;7:477. https://doi.org/10.1186/s13071-014-0477-7.

32. Stübs J. Untersuchungen über die Zeckenfauna einheimischer Wildsäuger. Ein Beitrag zur Kenntnis der Zeckenfauna Mecklenburgs. Wiss Z Univ Greifswald. 1960;9:177-88.

33. Szell Z, Sreter-Lancz Z, Marialigeti K, Sreter T. Temporal distribution of Ixodes ricinus, Dermacentor reticulatus and Haemaphysalis concinna in Hungary. Vet Parasitol. 2006;141(3-4):377-9. https://doi.org/10.1016/j. vetpar.2006.06.008.

34. Frimmel S, Krienke A, Riebold D, Loebermann M, Littmann M, Fiedler $\mathrm{K}$, et al. Tick-borne encephalitis virus habitats in north east Germany: reemergence of TBEV in ticks after 15 years of inactivity. Biomed Res Int. 2014;2014:308371. https://doi.org/10.1155/2014/308371.

35. Frimmel S, Leister M, Lobermann M, Feldhusen F, Seelmann M, Suss J, et al. Seroprevalence of tick-borne-encephalitis virus in wild game in Mecklenburg-Western Pomerania (north-eastern Germany). Ticks TickBorne Dis. 2016;7(6):1151-4. https://doi.org/10.1016/j.ttbdis.2016.08.004.

36. Frimmel S, Lobermann M, Feldhusen F, Seelmann M, Stiasny K, Suss J, et al. Detection of tick-borne encephalitis virus antibodies in sera of sheep and goats in Mecklenburg-Western Pomerania (north-eastern Germany). Ticks Tick-Borne Dis. 2019;10(4):901-4. https://doi.org/10.1016/j. ttbdis.2019.04.012.

37. Hersh MH, Tibbetts M, Strauss M, Ostfeld RS, Keesing F. Reservoir competence of wildlife host species for Babesia microti. Emerg Infect Dis. 2012;18(12):1951-7. https://doi.org/10.3201/eid1812.111392.

38. Franke J, Hildebrandt A, Meier F, Straube E, Dorn W. Prevalence of Lyme disease agents and several emerging pathogens in questing ticks from the German Baltic Coast. J Med Entomol. 2011;48(2):441-4. https://doi. org/10.1603/Me10182.

39. Blazejak K, Janecek E, Strube C. A 10-year surveillance of Rickettsiales (Rickettsia spp. and Anaplasma phagocytophilum) in the city of Hanover, Germany, reveals Rickettsia spp. as emerging pathogens in ticks. Parasite Vector. 2017;10:ARTN 588. https://doi.org/10.1186/s13071-017-2537-2.

40. Scarpulla M, Barlozzari G, Salvato L, De Liberato C, Lorenzetti R, Macri G. Rickettsia helvetica in Human-Parasitizing and Free-Living Ixodes ricinus from Urban and Wild Green Areas in the Metropolitan City of Rome, Italy. Vector borne and zoonotic diseases (Larchmont, NY). 2018;18(8):404-7. https://doi.org/10.1089/vbz.2017.2235.

41. Fingerle V, Munderloh UG, Liegl G, Wilske B. Coexistence of ehrlichiae of the phagocytophila group with Borrelia burgdorferi in Ixodes ricinus from Southern Germany. Med Microbiol Immunol. 1999;188(3):145-9. https:// doi.org/10.1007/s004300050117.

42. Krause PJ, Fish D, Narasimhan S, Barbour AG. Borrelia miyamotoi infection in nature and in humans. Clin Microbiol Infect. 2015;21(7):631-9. https:// doi.org/10.1016/j.cmi.2015.02.006.

43. Richter D, Schlee DB, Matuschka FR. Relapsing fever-like spirochetes infecting European vector tick of Lyme disease agent. Emerg Infect Dis. 2003;9(6):697-701.

44. Geller J, Nazarova L, Katargina O, Jarvekulg L, Fomenko N, Golovljova I. Detection and genetic characterization of relapsing fever spirochete Borrelia miyamotoi in Estonian ticks. PLoS ONE. 2012;7(12):e51914. https:// doi.org/10.1371/journal.pone.0051914.

45. May K, Strube C. Prevalence of Rickettsiales (Anaplasma phagocytophilum and Rickettsia spp.) in hard ticks (Ixodes ricinus) in the city of Hamburg, Germany. Parasitol Res. 2014;113(6):2169-75. https://doi.org/10.1007/ s00436-014-3869-x.

46. Portillo A, Ibarra V, Santibanez S, Perez-Martinez L, Blanco JR, Oteo JA. Genetic characterisation of $\mathrm{OmpA}$, $\mathrm{OmpB}$, and g/tA genes from Candidatus Rickettsia rioja. Clin Microbiol Infect. 2009;15(Suppl 2):307-8. https://doi. org/10.1111/j.1469-0691.2008.02250.x.

47. Fuehrer HP, Biro N, Harl J, Worliczek HL, Beiglbock C, Farkas R, et al. Molecular detection of Theileria sp. ZS TO4 in red deer (Cervus elaphus) and questing Haemaphysalis concinna ticks in Eastern Austria. Vet Parasitol. 2013;197(3-4):653-7. https://doi.org/10.1016/j.vetpar.2013.07.005.

48. Hornok S, Takacs N, Kontschan J, Gyorgy Z, Micsutka A, Iceton S, et al. Diversity of Haemaphysalis-associated piroplasms of ruminants in CentralEastern Europe, Hungary. Parasit Vectors. 2015;8:627. https://doi.org/10. 1186/s13071-015-1236-0.

49. Hamsikova Z, Kazimirova M, Harustiakova D, Mahrikova L, Slovak M, Berthova $L$, et al. Babesia spp. in ticks and wildlife in different habitat types of Slovakia. Parasit Vectors. 2016;9(1):292. https://doi.org/10.1186/ s13071-016-1560-z.

50. Tamura K, Nei M. Estimation of the number of nucleotide substitutions in the control region of mitochondrial DNA in humans and chimpanzees. Mol Biol Evol. 1993;10(3):512-26. https://doi.org/10.1093/oxfordjournals. molbev.a040023.

51. Chitimia L, Lin RQ, Cosoroaba I, Wu XY, Song HQ, Yuan ZG, et al. Genetic characterization of ticks from southwestern Romania by sequences of mitochondrial cox1 and nad5 genes. Exp Appl Acarol. 2010;52(3):305-11. https://doi.org/10.1007/s10493-010-9365-9.

52. Casati S, Sager H, Gern L, Piffaretti JC. Presence of potentially pathogenic Babesia sp. for human in Ixodes ricinus in Switzerland. Ann Agr Env Med. 2006;13(1):65-70.

53. Regnery RL, Spruill CL, Plikaytis BD. Genotypic identification of rickettsiae and estimation of intraspecies sequence divergence for portions of 2 Rickettsial Genes. J Bacteriol. 1991;173(5):1576-89. https://doi.org/10. 1128/jb.173.5.1576-1589.1991.

54. Roux V, Fournier PE, Raoult D. Differentiation of spotted fever group rickettsiae by sequencing and analysis of restriction fragment length polymorphism of PCR-amplified DNA of the gene encoding the protein rOmpA. J Clin Microbiol. 1996;34(9):2058-65. https://doi.org/10.1128/jcm. 34.9.2058-2065.1996.

55. Choi YJ, Jang WJ, Kim JH, Ryu JS, Lee SH, Park KH, et al. Spotted fever group and typhus group rickettsioses in humans, South Korea. Emerg Infect Dis. 2005;11(2):237-44. https://doi.org/10.3201/eid1102.040603.

56. Bunikis J, Garpmo U, Tsao J, Berglund J, Fish D, Barbour AG. Sequence typing reveals extensive strain diversity of the Lyme borreliosis agents Borrelia burgdorferi in North America and Borrelia afzelii in Europe. Microbiol-Sgm. 2004;150:1741-55. https://doi.org/10.1099/mic.0.26944-0.

57. Courtney JW, Kostelnik LM, Zeidner NS, Massung RF. Multiplex real-time PCR for detection of Anaplasma phagocytophilum and Borrelia burgdorferi. J Clin Microbiol. 2004;42(7):3164-8. https://doi.org/10.1128/jcm.42.7. 3164-3168.2004. 
58. Schwaiger M, Cassinotti P. Development of a quantitative real-time RT-

PCR assay with internal control for the laboratory detection of tick borne encephalitis virus (TBEV) RNA. J Clin Virol. 2003;27(2):136-45. https://doi. org/10.1016/S1386-6532(02)00168-3.

\section{Publisher's Note}

Springer Nature remains neutral with regard to jurisdictional claims in published maps and institutional affiliations.

- fast, convenient online submission

- thorough peer review by experienced researchers in your field

- rapid publication on acceptance

- support for research data, including large and complex data types

- gold Open Access which fosters wider collaboration and increased citations

- maximum visibility for your research: over $100 \mathrm{M}$ website views per year

At BMC, research is always in progress.

Learn more biomedcentral.com/submissions 